\title{
CAUCHY-SCHWARZ TYPE INEQUALITIES AND APPLICATIONS TO NUMERICAL RADIUS INEQUALITIES
}

\author{
FuAd KitTAneH And HAmid ReZA MORADi
}

Abstract. We present new improvements of certain Cauchy-Schwarz type inequalities. As applications of the results obtained, we provide refinements of some numerical radius inequalities for Hilbert space operators. It is shown, among other inequalities, that if $A \in \mathbb{B}(\mathscr{H})$, then

$$
\omega^{2}(A) \leqslant \frac{1}{6}\left\||A|^{2}+\left|A^{*}\right|^{2}\right\|+\frac{1}{3} \omega(A)\left\||A|+\left|A^{*}\right|\right\| .
$$

Mathematics subject classification (2010): 47A12, 47A30, 15A60.

Keywords and phrases: Cauchy-Schwarz inequality, numerical radius, operator norm, mixed Schwarz inequality.

\section{REFERENCES}

[1] J. Aujla And F. Silva, Weak majorization inequalities and convex functions, Linear Algebra Appl. 369 (2003), 217-233.

[2] P. BhUnia, S. BAG, AND K. PAUl, Numerical radius inequalities and its applications in estimation of zeros of polynomials, Linear Algebra Appl. 573 (2019), 166-177.

[3] M. L. BuZAno, Generalizzazione della diseguaglianza di Cauchy-Schwarz, (Italian), Rend. Sem. Mat. Univ. e Politech. Torino. 31 (1971/73), 405-409 (1974).

[4] S. S. DRAGOMIR, Power inequalities for the numerical radius of a product of two operators in Hilbert spaces, Sarajevo J. Math. 5(18) (2009), 269-278.

[5] T. Furuta, J. MićIĆ, J. PeČARIĆ, AND Y. SEO, Mond-Pečarić method in operator inequalities, Element, Zagreb, 2005.

[6] P.R. Halmos, A Hilbert space problem book, 2nd ed., Springer, New York, 1982.

[7] F. KitTANEH, A numerical radius inequality and an estimate for the numerical radius of the Frobenius companion matrix, Studia Math. 158(1) (2003), 11-17.

[8] F. KitTANeH, Numerical radius inequalities for Hilbert space operators, Studia Math. 168(1) (2005), $73-80$.

[9] M. E. Omidvar, H. R. Moradi, AND K. Shebrawi, Sharpening some classical numerical radius inequalities, Oper. Matrices. 12(2) (2018), 407-416. 